\title{
A Systematic Study of the Genus Spirillum which Occurs in Oxidation Ponds, with a Description of a New Species
}

\author{
BY W. A. PRETORIUS \\ National Institute for Water Research, Council for Scientific and Industrial Research, \\ P.O. Box 395, Pretoria, Republic of South Africa
}

(Received 25 February 1963)

\begin{abstract}
SUMMARY
A systematic study of the spiral form bacterial flora of oxidation ponds has been made. Three known species, namely $S$ pirillum itersonii, $S$. serpens and $S$. volutans, were constantly found. A primary enrichment medium for $S$. volutans from natural sources is given. A new species has been isolated; its main characters are: strictly aerobic, catalase-positive, does not grow under anaerobic conditions in the presence of nitrate, forms microcysts, differs in carbon-source utilization from previous described species. The species has been named Spirillum peregrinum.
\end{abstract}

\section{INTRODUCTION}

With the exception of a few members of the genus Spirillum Ehrenberg (Carter, 1888; Cayton \& Preston, 1955) all the species so far studied have been isolated from various sources of fresh and salt water containing organic matter (Lewis, 1940; Myers, 1940; Williams \& Rittenberg, 1957). Freshwater ponds containing large quantities of organic matter were established when domestic sewage was treated by the oxidation pond system of sewage purification, and it was therefore expected that various species of this genus would be present in such ponds. Apparently a systematic investigation of the spiral form bacterial population of oxidation ponds has not before been attempted. Such a study might prove to be an addition to the existing knowledge of the microbial population of oxidation ponds. Spiral bacterial forms from such ponds were enriched and isolated according to the procedures given below. The cultural characteristics of the isolates obtained are reported and have lead to the clear separation of a new species of the genus Spirillum, a description of which is given.

\section{METHODS}

\section{Method of primary enrichment}

Samples of oxidation pond water were taken near the inlet and outlet of a primary oxidation pond. The samples were first agitated in a macerator (Townson and Mercer, Croydon, England) for $10 \mathrm{sec}$. and then enrichment cultures were made in $250 \mathrm{ml}$. cotton-wool stoppered Erlenmeyer flasks by mixing $50 \mathrm{ml}$. inoculum with equal volumes of the following media:

Medium (a). An infusion of $1 \mathrm{~g}$. dried grass (small pieces) in $100 \mathrm{ml}$. distilled water at $100^{\circ}$ for $1 \mathrm{hr}$., keeping the volume constant. This infusion was used as it was, or with the solids filtered off. 
Medium (b). A defined medium as described by Myers (1940) with calcium lactate as carbon source and $\mathrm{NH}_{4} \mathrm{Cl}$ as nitrogen source.

Medium (c). A basal medium of the following composition: $\mathrm{K}_{2} \mathrm{HPO}_{4}, \mathbf{1} \cdot 0 \mathrm{~g}$.; $\left(\mathrm{NH}_{4}\right)_{2} \mathrm{SO}_{4}, 1 \cdot 0 \mathrm{~g}$.; $\mathrm{NaCl}, 1.0 \mathrm{~g}$.; $\mathrm{MgSO}_{4} .7 \mathrm{H}_{2} \mathrm{O}, 1.0 \mathrm{~g}$.; $\mathrm{MnSO}_{4}$ and $\mathrm{FeCl}_{3}$, one drop of a $1 \%(\mathrm{w} / \mathrm{v})$ solution of each; peptone (Evans), $1 \cdot 0 \mathrm{~g}$.; distilled water $1000 \mathrm{ml}$. Glucose, fructose, ethanol, glycerol, calcium lactate, cellulose powder (Whatman standard grade) and cellobiose were used as sources of carbon, at $1.0 \%(\mathrm{w} / \mathrm{v})$. With the exception of glucose, fructose and cellobiose of which solutions were Seitzfiltered and added to the heat-sterilized medium, all other carbon compounds were added before sterilization at $121^{\circ}$ for $15 \mathrm{~min}$.

After mixing with the inoculum the $\mathrm{pH}$ value of the mixtures were checked and when necessary adjusted to $\mathrm{pH} 7 \cdot 0$ with diluted $\mathrm{NaOH}$ or $\mathrm{HCl}$. All flasks were incubated at $30^{\circ}$.

\section{Isolation of pure cultures}

All enrichment cultures were first examined microscopically for the presence of spiral bacteria. The different morphological types were noted and an attempt then made to isolate a representative of each of the morphological types.

To allow the spirilla to become dominant it was often necessary to do serial enrichment cultures. This was done by the capillary tube method described by Rittenberg \& Rittenberg (1962). This method made it possible in a few cases to separate the spiral forms, to a certain extent, not only from non-motile forms, but also from motile forms other than spirilla. The media used here were (Difco) nutrient broth or medium $(c)$ with cellulose as carbon source.

After incubation of these subenrichment cultures for 2 days at $30^{\circ}$, no difficulty was encountered in isolating pure cultures by streaking on nutrient agar and/or cellulose-supplemented medium $(c)+1 \cdot 5 \%$ Bacto agar.

In all the primary medium $(c)+$ cellulose enrichment cultures, a giant spiral bacterium was noted. All attempts to isolate this bacterium by the above methods were unsuccessful. However, pure cultures were eventually isolated by using the dialysis bag method of Rittenberg \& Rittenberg (1962).

\section{Identification of isolated spirilla}

Observations and staining technique. For the estimation of size (by eye-piece micrometer), suspensions of $24 \mathrm{hr}$. nutrient broth cultures were used, the organisms being fixed by exposure to $2 \cdot 0 \%(\mathrm{w} / \mathrm{v})$ osmic acid for $30 \mathrm{sec}$. For the demonstration of flagella, Leifson's (1960) method was used. Volutin granules were demonstrated by the method described by Jörgensen (1948). Hucker's modification (Manual, 1957) of Gram's method was used to stain heat-fixed films.

Colony form. Cultures were grown on (Difco) nutrient agar, and on potato glucose agar (adjusted to $\mathrm{pH} \mathbf{7 \cdot 0}$ with sodium carbonate). Colony form was recorded after incubation for 2 days.

Oxygen requirements. These were tested by the shake tube method with $15 \mathrm{ml}$. nutrient agar in $6 \times \frac{5}{8}$ in. test tubes, and examined after 7 days. Nitrate broth (Difco) tubes were placed in boiling water for 15 min., immediately cooled down, inoculated, and sealed with wax.

Growth temperatures. Nutrient agar (Difco) slopes were incubated at the following temperatures: $10^{\circ}, 20^{\circ}, 30^{\circ}, 40^{\circ}, 45^{\circ}$ and $50^{\circ}$. 
$p H$ value for growth. The defined medium of Giesberger (1936; $\mathrm{NH}_{4} \mathrm{Cl}, 0 \cdot 1 \%$; $\mathrm{K}_{2} \mathrm{HPO}_{4}, 0.05 \% ; \mathrm{MgSO}_{4}, 0.05 \%$ ) with $0.2 \%(\mathrm{w} / \mathrm{v})$ calcium lactate was used, and samples were adjusted with diluted $\mathrm{HCl}$ or $\mathrm{KOH}$ to give a range of $\mathrm{pH}$ values between $5 \cdot 0$ and $9 \cdot 0$ at 1 unit intervals.

Nitrate reduction. Nitrate broth (Difco) with Durham fermentation tubes, was used. Cultures were tested with Griess-Ilosvay's reagents (with dimethyl- $\alpha$ naphthylamine) after 5 days. Zinc metal was added to the negative cultures and when found again negative, tested for ammonia with Nessler's reagent.

Gelatin hydrolysis. Stab cultures were made in Difco nutrient gelatin and incubated at $20^{\circ}$ for 14 days.

Catalase production. Growth from a $24 \mathrm{hr}$. nutrient agar slope was placed into a drop of ' 10 vol.' $\mathrm{H}_{2} \mathrm{O}_{2}$ solution and examined for production of gas bubbles.

Utilization of carbon compounds. The method of Williams \& Rittenberg (1957) was used. Carbon sources were added to $0 \cdot 2 \%(\mathrm{w} / \mathrm{v})$ in Giesberger's basal medium. Organic acid solutions were neutralized with $\mathrm{KOH}$ and sterilized separately by autoclaving momentarily at $111^{\circ}$ before adding to basal medium.

\section{RESULTS}

\section{Primary enrichment media}

By microscopical examination of the primary enrichment cultures, it was observed that the different media differed in selectivity for spiral organisms. For example, medium $(c)+1 \%(\mathrm{w} / \mathrm{v})$ cellulose powder allowed the growth of a large spiral organism and numerous small spiral bacteria. From the various enrichment media, representative spirilla were eventually obtained in pure cultures which could be classified into four different morphological groups. The number of isolates and some measurements of the different groups are given in Table 1. The organisms of all cultures were Gram-negative with bipolar tufts of flagella and, except for group I organisms, all groups showed volutin granules.

Table 1. Measurements and some characteristics of isolated spirilla

\begin{tabular}{|c|c|c|c|c|c|c|c|}
\hline \multirow{2}{*}{$\begin{array}{c}\text { Morpho- } \\
\text { logical } \\
\text { group }\end{array}$} & \multirow{2}{*}{$\begin{array}{c}\text { No. } \\
\text { of } \\
\text { isolates }\end{array}$} & \multicolumn{4}{|c|}{ Measurements of organisms $(\mu)$} & \multirow[b]{2}{*}{$\begin{array}{l}\text { Volutin } \\
\text { granules }\end{array}$} & \multirow{2}{*}{$\begin{array}{l}\text { Micro- } \\
\text { cysts } \\
\text { formed }\end{array}$} \\
\hline & & Diameter & $\begin{array}{l}\text { Spiral } \\
\text { pitch }\end{array}$ & $\begin{array}{l}\text { Spiral } \\
\text { width }\end{array}$ & $\begin{array}{l}\text { Length of } \\
\text { organism }\end{array}$ & & \\
\hline $\mathbf{I}$ & 4 & $0 \cdot 5-6 \cdot 5$ & $3 \cdot 25$ & $\mathbf{1} \cdot \mathbf{3}$ & $4 \cdot 6-5 \cdot 8$ & Not seen & Yes \\
\hline $\mathbf{I I}$ & 5 & $0 \cdot 7-8 \cdot 5$ & $6 \cdot 5-9 \cdot 0$ & $1 \cdot 5-3 \cdot 7$ & $6 \cdot 0-3 \cdot 7$ & Present & Yes \\
\hline III & 9 & $0.9-1.3$ & $6.5-8.0$ & $2 \cdot 5-3 \cdot 0$ & $10-22$ & Present & Not seen \\
\hline IV & 6 & $1 \cdot 5-2 \cdot 0$ & 6-9 & $9-20$ & $24-49$ & Present & Not seen \\
\hline
\end{tabular}

Colony form. The colonies of the spirilla isolated had a characteristic granular appearance. Colony formation was good on nutrient agar and on potato glucose agar. The general appearances corresponded to those described by Williams \& Rittenberg (1957). On no occasion, however, was it possible to obtain group IV (Table 1) organisms in pure culture other than in the dialysis bags. This organism did not grow in pure culture in the media tested, so that no growth characteristics have been obtained.

Oxygen requirements. By the shake tube method all cultures behaved in the same way: growth was profuse only at the top of the tube. With nitrate broth incubated 
anaerobically, only cultures of group I grew well; none of the others showed growth.

Growth temperatures. All cultures grew between $10^{\circ}$ and $30^{\circ}$; the organisms of group I also grew well at $40^{\circ}$ but did not grow at $45^{\circ}$.

$p H$ range. The $\mathrm{pH}$ ranges over which growth occurred in a defined medium with lactate was as follows: group I, below $5 \cdot 0$ to more than $9 \cdot 0$; group II, from $5 \cdot 0$ to $8 \cdot 0$, not at $9 \cdot 0$; group III, from $6 \cdot 0$ to $8 \cdot 0$, not at $9 \cdot 0$. Group IV organisms grew in cellulose enrichment medium (i.e. not in pure culture) between $\mathrm{pH} 6 \cdot 0$ and $\mathbf{7 \cdot 5}$.

Apart from morphological differences between the groups, the biochemical activities also differed markedly.

Nitrate reduction. Group I organisms reduced nitrate, the isolates of the other groups did not. Group I isolates reduced nitrate to nitrite after $\mathbf{2 4} \mathrm{hr}$. and completely to ammonia in $48 \mathrm{hr}$.

Gelatin hydrolysis. Only organisms of group III showed weak gelatin hydrolysis after 14 days.

Catalase reaction. All cultures were catalase-positive. The catalase reaction of group II organisms was strong, while that of groups I and III was so weak that it was at first thought to be negative.

Utilization of carbon compounds. The ability to utilize organic compounds as sole carbon source is summarized in Table 2.

Table 2. Utilization of compounds as nutrients

Morphological
group
I
II
III
Morphological
group But
I
II
III

(a) Utilization of compounds singly as carbon sources

(b) Utilization of nitrogen sources with succinate as sole carbon source

Group I
Group II
Group III

$\begin{array}{cc}\text { Citrate } & \text { Lactate } \\ + & + \\ + & + \\ - & +\end{array}$

Malate
+
+
+

$\begin{array}{ccc}\text { Fumarate } & \text { Succinate } & \text { Pyruvate } \\ + & + & + \\ + & + & + \\ + & - & -\end{array}$

Butyrate Propionate Acetate

$\begin{array}{ccccc}\text { cetate } & \text { Fructose } & \text { Glucose } & \text { Glycerol } & \text { Ethanol } \\ + & + & + & + & + \\ + & + & - & - & + \\ + & - & - & - & -\end{array}$

$\mathrm{KNO}_{3}$
Urea $\mathrm{NH}_{4} \mathrm{Cl}$ Asparagine

Group III

$\begin{array}{llll}+ & + & + & + \\ + & + & + & + \\ - & + & + & +\end{array}$

\section{DISCUSSION}

From the data obtained, the morphological groups I, III and IV were found to be made up of the following species: Spirillum itersonii, $S$. serpens and $S$. volutans, respectively. The dimensions of the organisms of group II closely resemble those of $S$. mancuniense, but differed in that they were all strongly catalase-positive, grew well in Difco nutrient broth and potato glucose agar and did not liquefy gelatin. The organisms of group II also differed from those species described and classified by Williams \& Rittenberg (1957); they are aerobic, do not grow anaerobically in the presence of nitrate, and form microcysts in old cultures. Their size and metabolic reactions differed from those of other freshwater microcyst-forming spiral bacteria 
so far described. It is not known whether these organisms are to be found only in oxidation pond water. Because the organisms of group II are the only unknown spirillum species isolated, the name $S$. peregrinum has been given to these organisms.

It is interesting to note that, apart from the two well-known species Spirillum itersonii and $S$. serpens, $S$. volutans also occurred very frequently in the oxidation ponds. The cellulose enrichment cultures, made from samples from various sewage works, were all positive for this organism; such sewages therefore seem to be a natural habitat of this organism.

\section{Spirillum peregrinum sp.nov.}

Growth in nutrient broth and Evans peptone $(1 \%$ w/v) water. In 18-24 hr. cultures the organisms are usually $6 \cdot 0 \mu \mathrm{long}$, with a spiral width of $2 \cdot 3 \mu$ and a diameter of $0 \cdot 8 \mu$. The organisms usually have a $S$-shape and when not it can be seen that the organism is composed of two or more S-shaped units. Tufts of flagella are formed at these joints (Pl. 1, fig. 1). Only a few organisms showed a granular appearance. In 2- to 3-week cultures, a white sediment formed, consisting of non-motile organisms and microcysts. The supernatant fluid, however, contained organisms of various spiral forms: some were short, thick, fast-moving organisms, others formed perfect rings with the ends open and of diameter $7.5 \mu$; the others were spiral organisms 22.5 $\mu$ long with a spiral pitch of $9 \cdot 0 \mu$ and a spiral width of $3 \cdot 7 \mu$. All organisms had a granular appearance, probably due to volutin granules (Pl. 1, fig. 2).

Growth in defined media containing lactate and pyruvate. Apart from the abovementioned forms, numerous long tightly coiled organisms appeared in these media; of length $37 \mu$, diameter $0.7 \mu$, spiral pitch $1.5 \mu$ and spiral width $1.5 \mu$. Typical appearances are shown in Pl. 1, fig. 3.

Microcysts. Microcysts are formed in 1-week and older cultures, are oval to ellipsoidal in early stages of formation, becoming spherical on ageing, the average diameter being 3.5 $\mu$. Although non-motile, these microcysts possessed polar tufts of flagella (Pl. 1, fig. 4). All organisms were Gram-negative with bipolar tufts of flagella.

Colonies on nutrient agar. Finely granular, round, greyish, 2-3 mm. diameter.

Potato glucose agar. Similar to nutrient agar, except that colonies were yellowishgrey.

Gelatin. Not liquefied.

Nitrogen sources. Ammonia, nitrate, urea and asparagine used with succinate as carbon source.

$\mathrm{pH}$ range. Growth occurred between $\mathrm{pH} 5 \cdot 0$ and 8:0.

Carbon sources. Grows well with salts of malonic, citric, lactic, malic, fumaric, succinic, pyruvic, propionic, butyric and acetic acids. Good growth with fructose or ethanol, but very poor or no growth with glucose or glycerol.

Aerobic catalase-positive; no growth under anaerobic conditions in the presence of nitrate.

Source. Isolated from primary oxidation pond water. A type culture has been deposited at the National Collection of Industrial Bacteria, Torry Research Station, Aberdeen, Scotland; the number assigned to it is NCIB 9435.

I am grateful to Mr M. L. Siebert and Miss Susanna I. Scholtz for their conscientious technical assistance and Dr B. J. Cholnoky for making the photographs. 


\section{REFERENCES}

Carter, (1888). Sci. Mem. Med. Offrs Army India, 3, 45. (According to Bergey's Manual of Determinative Bacteriology (1957), 7th ed. Ed. by R. S. Breed, E. G. D. Murray and N. R. Smith. Baltimore: Williams and Williams.)

Cayton, H. R. \& Preston, N. W. (1955). Spirillum mancuniense n.sp. J. gen. Microbiol. $12,519$.

Jörgensen, A. (1948). Micro-organisms and Fermentation. London: Charles Griffen and Co.

Leifson, E. (1960). Atlas of Bacterial Flagellation. New York and London: Academic Press.

LEwIs, I. M. (1940). The genus Spirillum Ehbg. with special reference to cell inclusions and chromidial theory. J. Bact. 40, 271.

Myers, J. (1940). Studies on the Spirilleae. Methods of isolation and identification. J. Bact. 40, 705.

Rittenberg, B. T. \& RitTenberg, S. C. (1962). The growth of Spirillum volutans Ehrenberg in mixed and pure cultures. Archiv. für Mikrobiologie, 42, 138.

Manual of Microbiological Methods, Society of American Bacteriologists (1957). New York: MeGraw Hill.

Williams, M. A. \& Rittenberg, S. C. (1957). A taxonomic study of the genus Spirillum Ehrenberg. Int. Bull. Bact. Nomen. Tax. 7, 49.

\section{EXPLANATION OF PLATE}

Fig. 1. Organisms from $48 \mathrm{hr}$. broth culture, showing flagella at poles and intersection. Leifson's flagella stain.

Fig. 2. Typical ring-shaped organism and two longer organisms in 2-week nutrient broth culture. Leifson's flagella stain.

Fig. 3. Long tightly coiled organisms in lactate broth. Methylene blue (1\%) stain.

Fig. 4. Microcyst with bipolar tufts of flagella. Leifson's flagella stain. 

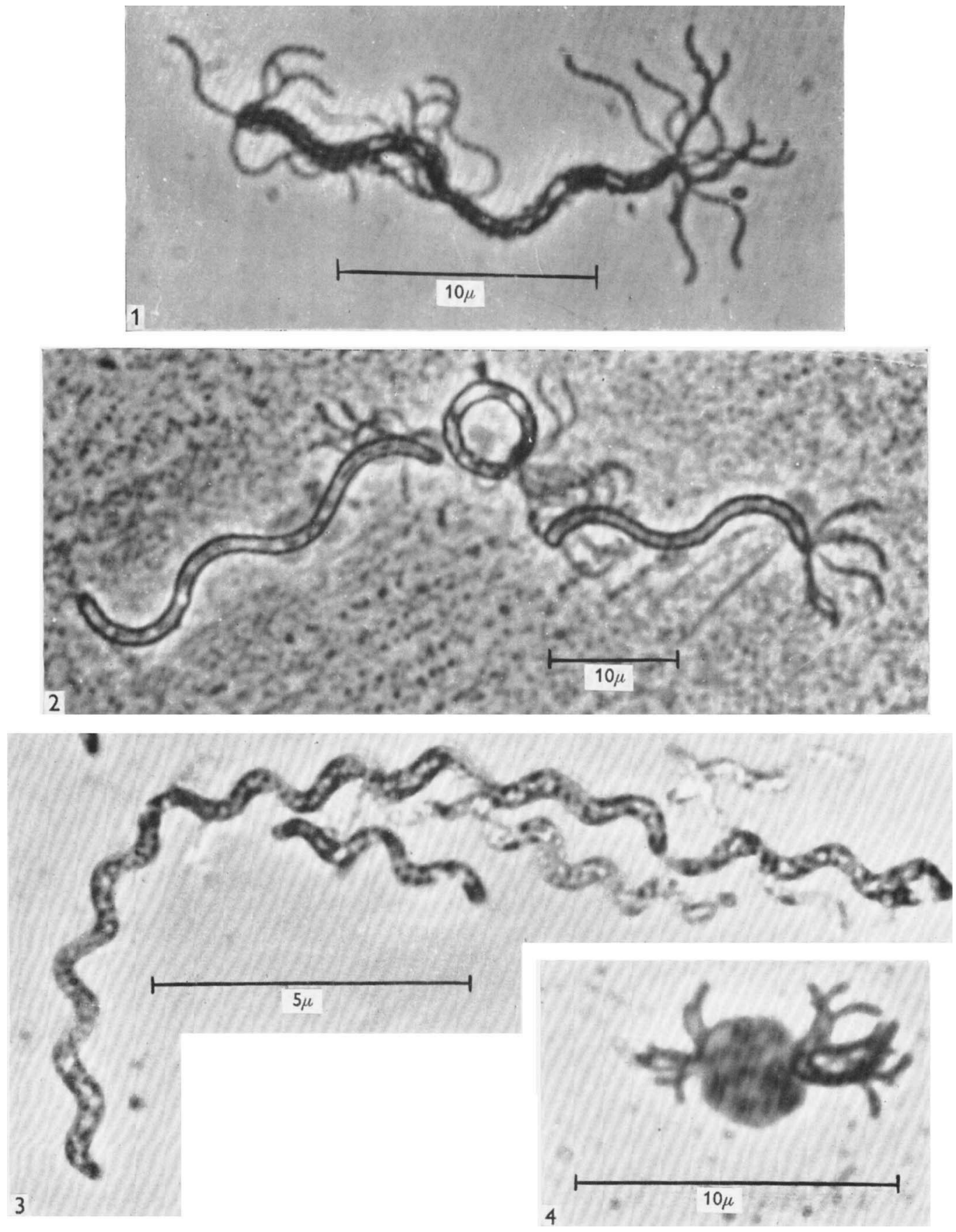